\title{
Muscle damage in $m d x$ (dystrophic) mice: The role of calcium and reactive oxygen species
}

\author{
Nicholas P. Whitehead, ${ }^{1}$ Ella W. Yeung ${ }^{2} \&$ David G. Allen ${ }^{1}$ \\ ${ }^{1}$ School of Medical Sciences, University of Sydney F13, NSW 2006, Australia and \\ ${ }^{2}$ Department of Rehabilitation Science, Hong Kong Polytechnic University, Hung Hom, Kowloon, Hong Kong
}

\section{Summary}

1. Duchenne muscular dystrophy is a lethal, degenerative muscle disease caused by a genetic mutation, which leads to complete absence of the cytoskeletal protein dystrophin in muscle fibres.

2. The present review provides an overview of some of the physiological pathways that might contribute to muscle damage and degeneration in DMD, based primarily on experimental findings in the $m d x$ mouse, an animal model of this disease.

3. A rise in intracellular calcium is widely thought to be an important initiating event in the dystrophic pathogenesis. The pathway(s) leading to increased intracellular calcium in dystrophin deficient muscle are uncertain but recent work from our laboratory provides evidence that stretch-activated channels (SACs) are an important source of the calcium influx. Other possible routes of calcium entry are also discussed.

4. The consequences of elevated cytosolic calcium may include activation of proteases, such as calpain, and increased production of reactive oxygen species (ROS), which can cause protein and membrane damage.

5. Another possible cause of damage in dystrophic muscle involves inflammatory pathways such as those mediated by neutrophils, macrophages and associated cytokines. There is recent evidence that increased ROS might be important in both the activation and damage caused by this inflammatory pathway in $m d x$ muscle.

\section{Introduction}

The muscular dystrophies are a collection of degenerative neuromuscular diseases. The most common and devastating form of muscular dystrophy is Duchenne muscular dystrophy (DMD), which affects 1 in every 3500 male births. DMD is characterised by progressive degeneration of skeletal muscle and an inability, over time, of the muscle to adequately repair itself, so that healthy muscle is gradually replaced by fat and connective tissue. This causes profound muscle weakness, such that affected individuals are often wheelchair-bound by the age of 10-12, and usually die of respiratory and/or cardiac failure by about the age of 20. Despite extensive research into the genetic and cellular mechanisms underlying DMD, currently there are no effective treatments for this disease.

It has been known for over a decade that DMD is caused by an $\mathrm{X}$-chromosome gene mutation resulting in the absence of the protein dystrophin in skeletal muscle. ${ }^{1}$
Dystrophin is a large protein $(427 \mathrm{kD})$ that links the cytoskeleton to a complex of proteins in the surface membrane of muscle fibres, which in turn interact with the extracellular matrix. The $m d x$ mouse, an animal model of $\mathrm{DMD}$, also has a genetic mutation resulting in the loss of dystrophin, although for reasons not entirely understood it has a relatively mild phenotype compared to individuals with DMD. ${ }^{2}$ Over the past $15-20$ years, the $m d x$ mouse has been widely used to investigate the mechanisms that cause dystrophic muscles to be more vulnerable to damage and degeneration. The $m d x$ mouse also has a key role in testing possible therapeutic interventions, which are aimed at slowing the progression of, or preventing, this disease. Existing studies suggest that multiple factors contribute to muscle damage in dystrophic muscle. The purpose of this review is to present some of the physiological pathways that might be involved in dystrophic muscle disease, with a particular focus on the effects of calcium $\left(\mathrm{Ca}^{2+}\right)$ and reactive oxygen species (ROS). A further aim is to try to establish how some of these damage pathways might interact, in an effort to provide a broader understanding of the dystrophic pathogenesis.

\section{Intracellular $\mathrm{Ca}^{2+}$ in dystrophic muscle}

Early research ${ }^{3}$ showed that the total $\mathrm{Ca}^{2+}$ measured in muscle biopsies from DMD patients was greater than that from normal muscle. While the general consensus from a number of studies is that the free intracellular $\mathrm{Ca}^{2+}$ concentration $\left(\left[\mathrm{Ca}^{2+}\right]_{\mathrm{i}}\right)$ is also higher in muscle fibres from $m d x$ mice compared to that measured in wild-type fibres, other papers have reported no significant rise in $\left[\mathrm{Ca}^{2+}\right]_{i}$ (see $^{4,5}$ for recent reviews). A possible reason why some investigators do not find elevated $\left[\mathrm{Ca}^{2+}\right]_{i}$ in $m d x$ muscle may be partly due to methodological differences between the various studies, particularly relating to the fluorescent indicators used to measure $\left[\mathrm{Ca}^{2+}\right]_{i}$ and the previous contractile activity and age of the cells. ${ }^{6}$ Also, for a period of time, $\mathrm{Ca}^{2+}$ entering the fibre can be effectively taken up by the mitochondria and sarcoplasmic reticulum (SR), and it has been shown that the $\mathrm{Ca}^{2+}$ concentration in the $\mathrm{SR}$ is greater in $m d x$ myotubes than in normal myotubes. ${ }^{7}$ Furthermore, it has also been reported that the $\left[\mathrm{Ca}^{2+}\right]_{i}$ in the subsarcolemmal space is about 3 times greater in $m d x$ muscle. $^{8}$ Thus, taking all of these observations into account, there is strong evidence to suggest that $\mathrm{Ca}^{2+}$ homeostasis is disturbed in dystrophic muscles. The next sections will discuss possible physiological pathways of $\mathrm{Ca}^{2+}$ entry and how $\mathrm{Ca}^{2+}$ might contribute to dystrophic 
muscle damage.

\section{$\mathrm{Ca}^{2+}$ entry pathways: Membrane tears or ion channels?}

Over the past 15 years or so, two main theories have been proposed as to why the absence of dystrophin causes muscles to be particularly susceptible to damage and degeneration. $^{9}$ (1) Dystrophin may have an important structural role in maintaining the integrity of the muscle fibre membrane during contraction, particularly those involving stretch. Thus, it is suggested that in the absence of dystrophin, stretched contractions lead to membrane tears. ${ }^{10}$ (2) Dystrophin may be involved in the aggregation of ion channels in the membrane and its absence may lead to abnormal channel function. ${ }^{11}$ According to both hypotheses, there would be a rise in $\left[\mathrm{Ca}^{2+}\right]_{i}$, a subsequent loss of $\mathrm{Ca}^{2+}$ homeostasis and the activation of various degradative pathways (discussed below), which lead to muscle fibre necrosis.

\section{Membrane tears}

It is well established that dystrophic muscles not only lack dystrophin but also have greatly reduced levels of many other dystrophin-associated membrane glycoproteins. ${ }^{12}$ Furthermore, some $m d x$ fibres from older mice have been shown to have abnormal architecture, with fibre splitting and branching. ${ }^{13}$ Thus, many investigators have postulated that these factors render the surface membrane of dystrophic fibres more susceptible to stresses imposed during contractions, particularly those involving stretch. ${ }^{10,13-15}$ According to this theory, transient membrane tears develop, thereby allowing extracellular $\mathrm{Ca}^{2+}$ to rapidly enter the fibre along its electrochemical gradient. However, although this is a plausible theory, is there any direct experimental evidence to support it?

While there is ample data showing that muscles from $m d x$ mice have increased membrane permeability, as shown by large plasma concentrations of muscle-specific enzymes such as creatine kinase (CK) and greater uptake of membrane impermeable dyes into dystrophic muscle fibres, ${ }^{16-18}$ this, in itself, does not support the idea that these movements are due to mechanical tears in the sarcolemma. Unfortunately, there are only a few studies that have attempted to address the issue of the mechanical strength of the dystrophic muscle fibre membrane. While the membrane stiffness of $m d x$ myotubes was found to be about four times less than that of normal myotubes, ${ }^{19}$ two earlier studies reported little or no difference in the tensile strength of the sarcolemma of muscle fibres from $m d x$ mice compared to wild-type, as assessed by measuring the suction required to burst membrane patches. ${ }^{11,20}$ Thus, it appears that while dystrophin is important for maintaining membrane stiffness, perhaps due to structural connections between the cytoskeleton, membrane and the extracellular matrix, the intrinsic strength of the sarcolemma seems to be a property of the lipid bilayer, which is not affected by the absence of dystrophin. ${ }^{21}$

\section{Ion Channels}

Since many ion channels are structurally linked to membrane-bound proteins, it has been hypothesized that the distribution and/or function of such channels might be altered in dystrophic muscle. Of particular interest are those channels that allow $\mathrm{Ca}^{2+}$ entry into muscle fibres. Steinhardt and colleagues have reported the presence of a $\mathrm{Ca}^{2+}$ leak channel, which has been shown to be more active in $m d x$ muscle, and thus might provide a source of $\mathrm{Ca}^{2+}$ entry into the fibre. ${ }^{22}$ This channel was found to have properties consistent with it being a store-operated channel ${ }^{6}$ and interestingly, its activity was enhanced by the L-type $\mathrm{Ca}^{2+}$ channel blocker, nifedipine, but blocked by the an analogue of nifedipine, known as AN 1043. ${ }^{23}$ Contractile activity was found to increase the activity of these leak channels in dystrophic muscle while leupeptin, an inhibitor of the protease calpain, could prevent the influx of $\mathrm{Ca}^{2+}$ through these channels. ${ }^{24}$ Based on these findings, it was hypothesized that previous contractile activity leads to transient membrane tears and localized influxes of $\mathrm{Ca}^{2+}$, which initiates the insertion of leak channels into the membrane, via an exocytotic pathway. The elevated $\mathrm{Ca}^{2+}$ also activates proteases, such as calpain, which are required to activate the leak channels. Opening of the leak channels leads to a persistent influx of $\mathrm{Ca}^{2+}$ and a self-perpetuating damage pathway then operates. ${ }^{25}$

At about the same time as the discovery of the $\mathrm{Ca}^{2+}$ leak channel in dystrophic muscle, the presence of a mechanosensitive cation channel was reported, ${ }^{11}$ which had a greater open probability in $m d x$ muscle fibres when the membrane was stretched by suction from a patch pipette. Importantly, the increase in activity of these mechanosensitive channels was evident from muscle fibres of young $m d x$ mice, before any signs of muscle damage and necrosis, ${ }^{26}$ suggesting it could be a primary source of $\mathrm{Ca}^{2+}$ entry in dystrophic muscle. In addition, the occurrence of these channels was also greater in $m d x$ fibres, suggesting there might be an increased density of these channels in the membrane. ${ }^{27,28}$ Recent research carried out in our laboratory has focused on the role of these mechanosensitive or stretch-activated channels (SACs) in dystrophic muscle damage. In single muscle fibres from $m d x$ mice, it has been found that a significant component of the force reduction and the rise of intracellular $\mathrm{Na}^{+}$caused by a series of stretched (eccentric) contractions can be prevented by two known SAC blockers, gadolinium and streptomycin. ${ }^{29}$ In a more recent series of experiments, ${ }^{30}$ it was found that the rise in $\left[\mathrm{Ca}^{2+}\right]_{\mathrm{i}}$ following stretched contractions of $m d x$ fibres could also be prevented by gadolinium, streptomycin and a new spider venom GsMTx4, the most potent and specific inhibitor of SACs yet identified. ${ }^{31}$ This study also showed a significant reduction in muscle damage, assessed histologically, in $m d x$ mice given streptomycin orally over two weeks. In a series of experiments currently in progress (Whitehead, Streamer \& Allen, unpublished observations) we have found that following stretched contractions of intact $m d x$ muscles, the uptake into muscle fibres of a membrane-impermeable 
fluorescent dye, procion orange, was relatively small immediately after the contractions but increased gradually over the following hour or so. Moreover, the number of fibres containing procion orange was greatly reduced when muscles were bathed in streptomycin or GsMTx4 prior to and after the stretched contractions. Taken together, these findings support the hypothesis that the primary source of $\mathrm{Ca}^{2+}$ entry in dystrophic muscle is through SACs and not via transient mechanical tears, and that the influx of $\mathrm{Ca}^{2+}$ though these channels contributes to the increased membrane permeability following stretched contractions of $m d x$ muscle. Of course, once the membrane becomes permeable, more $\mathrm{Ca}^{2+}$ can then enter the fibre and potentially activate the $\mathrm{Ca}^{2+}$ leak channel, as discussed earlier, thereby providing an additional route for $\mathrm{Ca}^{2+}$ entry.

In a recent clinical trial, the antiobiotic gentamicin, which, like streptomycin, also blocks SACs, was administered to DMD patients to suppress nonsense mutations in the dystrophin gene. ${ }^{32}$ Interestingly, while there was no detectable dystrophin expression following 2 weeks of treatment, all 4 patients showed a reduction in serum CK levels. The authors speculated that this result was due to altered activity levels during the trial, however an alternate hypothesis is that gentamicin blocked SACs and reduced CK release from muscles, as outlined earlier.

In a recent paper, experimental findings suggested that the canonical transient receptor potential channel 1 (TRPC1) forms the stretch-activated cation channel in vertebrate cells. ${ }^{33}$ This discovery opens up the possibility of utilising more molecular-based techniques to identify these channels and to investigate their function in dystrophic muscles. Interestingly, there is already some evidence that TRPC1, 4 and 6 are present in the sarcolemma of skeletal muscle fibres and that repression of TRPC1 and 4 in $m d x$ muscle, using antisense oligonucleotides, greatly diminished the activity of $\mathrm{Ca}^{2+}$ channels, which had electrophysiological properties consistent with both store-operated channels and SACs. ${ }^{28}$

There are a number of independent experimental findings, which might explain why SACs (TRPC1) are overexpressed in $m d x$ muscle and why these channels are more prone to opening during stretch. Firstly, caveolin-3, the main protein component of caveolae in skeletal muscle, is known to be overexpressed in $m d x$ mice and displays an irregular membrane distribution. ${ }^{34}$ Since caveolin-1, which has a similar overall structure to caveolin- 3,35 is known to bind TRPC1 in smooth muscle cells ${ }^{36}$ this could mean that by having increased caveolin-3 expression in dystrophic muscle, TRPC1 expression might also be greater. In fact, there is a suggestion from Western blots that TRPC1 levels are increased in $m d x$ muscle compared to wild-type, ${ }^{28}$ although this point was not specifically raised by the authors of this paper. Furthermore, recent work from our laboratory has shown that TRPC1 levels are greater in cardiac muscle from old $m d x$ mice compared to wild-type (Williams \& Allen, unpublished observations). In relation to this idea, it has recently been shown in endothelial cells that TRPC1 expression can be increased by the proinflammatory cytokine, tumour necrosis factor $(\mathrm{TNF} \alpha),{ }^{37}$ which is intriguing in light of the fact that the levels of $\mathrm{TNF} \alpha$ are enhanced in $m d x$ muscle. ${ }^{38}$ A final point of interest is that caveolin-3 interacts with $\beta$-dystroglycan, to which dystrophin normally binds, and is thought to compete with dystrophin for this binding site. ${ }^{39}$ Therefore, the interactions between dystrophin, its associated membranebound glycoprotein complex, and caveolin-3, are likely to be critically important in the expression and function of ion channels, such as TRPC1.

\section{Calcium and muscle damage in dystrophic muscle}

\section{Proteases}

It has been postulated for many years that calcium-activated proteases are involved in protein degradation and subsequent necrosis of dystrophic muscle. ${ }^{40}$ Particular attention has been given to the calciumactivated cysteine protease, calpain, which is known to degrade a wide range of skeletal muscle proteins, including some cytoskeletal and membrane proteins. ${ }^{41,42}$

Calpain activity has been shown to be greater in muscles from $m d x$ mice than wild-type mice ${ }^{43}$ and it has been reported that the increased calpain activity in $m d x$ mice occurs during periods of both muscle degeneration and regeneration. ${ }^{44}$ When the calpain inhibitor, leupeptin, was injected intramuscularly for 30 days, muscle degeneration and necrosis was reduced in $m d x$ muscles by up to $50 \%{ }^{45}$ Using a different experimental approach, ${ }^{46}$ an $m d x$ transgenic mouse was developed to overexpress calpastatin, an endogenous calpain inhibitor. It was found that the calpastatin transgenic mice had fewer necrotic muscle fibres and had less regenerated fibres, indicating a reduction in accumulated muscle damage, however membrane permeability was unaffected.

\section{Reactive Oxygen Species (ROS)}

ROS have been proposed, over many years, as possible mediators of dystrophic muscle damage. Much of the work on the effects of ROS on $m d x$ muscle has been carried out by Rando and colleagues. This group has provided evidence that $m d x$ muscle is more susceptible to ROS-induced damage ${ }^{47}$ and that the increased production of ROS causes lipid peroxidation in the period preceding any necrosis in $m d x$ mice. ${ }^{48}$ This finding suggests that ROS might be involved as a primary rather than secondary cause of degeneration. This hypothesis is supported by two in vivo studies, which showed signs of reduced muscle damage in $m d x$ mice given antioxidants derived from green tea ${ }^{49}$ or fed a low iron diet, which reduces the production of hydroxyl radicals. ${ }^{50}$ Although previous clinical trials have shown no significant therapeutic effect of certain antioxidants on DMD muscles, ${ }^{51,52}$ these studies were carried out on some patients already undergoing muscle degeneration, which may have limited their effectiveness. Also, depending on the type(s) of ROS produced by dystrophic muscles, some antioxidants may be more effective than others in preventing oxidative damage.

An important question is to elucidate the cause(s) of 
the increased ROS production in dystrophic muscle. It is known that abnormal uptake of $\mathrm{Ca}^{2+}$ by mitochondria can result in greater production of ROS. ${ }^{53,54}$ This is a likely source of ROS in dystrophic muscle given that mitochondrial oxidative phosphorylation was shown to be impaired in $m d x$ mice, and this was postulated to be due to mitochondrial $\mathrm{Ca}^{2+}$ overload. ${ }^{55}$ This idea is also strengthened by experiments showing that an elevated intracellular $\mathrm{Ca}^{2+}$ in normal skeletal muscle leads to increased membrane permeability, which could be most effectively prevented by deferoxamine, an iron chelator that stops the production of the highly reactive hydroxyl radicals. ${ }^{56}$ This study also showed that blocking calciumdependent phospholipase A2 $\left(\mathrm{PLA}_{2}\right)$ activation also prevented some of the increased membrane permeability. Interestingly, $\mathrm{PLA}_{2}$ activity in muscles from DMD patients has been shown to be significantly greater than that measured in normal muscles. ${ }^{57} \mathrm{PLA}_{2}$ might partially work in conjunction with ROS in causing increased membrane permeability in dystrophic muscle, since there is some evidence that $\mathrm{PLA}_{2}$ is very effective at removing oxidized fatty acids from isolated lipososmes. ${ }^{58}$

ROS have also been implicated in the passive stretchinduced activation of the transcription factor, NF- $\mathrm{BB}$, in $m d x$ muscle, since NF- $\kappa \mathrm{B}$ activation could be prevented by the antioxidant NAC. ${ }^{38}$ The role of NF- $\kappa \mathrm{B}$ in dystrophic muscle damage will be discussed in the next section. Interestingly, the SAC blocker, gadolinium, was not very effective at preventing the activation of $\mathrm{NF}-\kappa \mathrm{B},{ }^{38}$ although a recent study suggests that both $\mathrm{Ca}^{2+}$ entry through SACs and increased ROS production contribute to NF- $\mathrm{BB}$ activation following stretch of fibroblast cells. ${ }^{59}$ Nevertheless, this raises the possibility that there is also a $\mathrm{Ca}^{2+}$-independent production of ROS in $m d x$ muscle, which is enhanced during passive stretch of the muscle. One possibility might be NADPH-oxidase, which is known to rapidly produce ROS, within one minute, during cyclic stretch of smooth muscle cells. ${ }^{60}$ It has been recently reported that in skeletal muscle, the NADPH-oxidase subunits are located in close proximity to the sarcolemma of muscle fibres. ${ }^{61}$ Thus, it is tempting to speculate that if this enzyme complex is somehow regulated by dystrophin, its associated membrane proteins, or other cytoskeletal structures, then its function may be altered in dystrophic muscle, and ROS production could be increased, particularly during stretch. This possibility awaits further experimental findings.

\section{ROS and inflammatory damage of dystrophic muscle.}

As mentioned earlier, the finding that ROS increases the activation of the NF- $\kappa \mathrm{B}$ pathway ${ }^{38}$ is significant because $\mathrm{NF}-\kappa \mathrm{B}$ is a transcription factor that regulates the expression of pro-inflammatory cytokines, such as TNF $\alpha$ and IL-1 $\beta$, which, in this study, were found to be increased in $m d x$ muscle before the period of muscle fibre necrosis. Since $\mathrm{TNF} \alpha$ can also stimulate the production of mitochondrial ROS, ${ }^{62}$ this could create a positive feedback loop whereby the increased ROS cause further activation of $\mathrm{NF}-\kappa \mathrm{B}$ as well as having their own deleterious effects on the muscle. ${ }^{38}$ This idea is supported by a recent paper which reported that $m d x$ mice injected with an anti-TNF $\alpha$ antibody, Remicade, displayed less muscle necrosis and reduced inflammatory cell infiltration than control $m d x$ mice. ${ }^{63}$ Inflammatory cells such as neutrophils and macrophages can also produce ROS, and it is thought that nitric oxide (NO) can scavenge ROS produced by imflammatory cells. ${ }^{64}$ In $m d x$ muscle nNOS is downregulated leading to a reduction in NO levels and therefore creating a situation where damage caused by ROS may be greater. The significance of the reduced NO levels in dystrophic muscle is highlighted by a study in which the upregulation of NO in muscles of $m d x$ mice, by using a NOS transgene, resulted in significant reductions in muscle damage, infiltrating inflammatory cells and plasma CK levels. ${ }^{65}$

\section{Conclusion}

It has been postulated for many years that a loss of $\mathrm{Ca}^{2+}$ homeostasis is a significant factor in dystrophic muscle degeneration. This review provides some new experimental evidence that the primary route of $\mathrm{Ca}^{2+}$ entry in $m d x$ muscle occurs via ion channels, particularly SACs, rather than through transient mechanical membrane tears. It is proposed that one important consequence of the increased $\left[\mathrm{Ca}^{2+}\right]_{i}$ is an enhanced production of ROS, which can cause muscle damage through direct effects on muscle fibre proteins and the membrane, as well as through the activation of inflammatory pathways. This is outlined schematically in Fig 1. While this review has focused mainly on the role of $\mathrm{Ca}^{2+}$ and ROS in dystrophic muscle degeneration, it is clear that there are likely be other physiological pathways, which also contribute to the damage process. Therefore, it is important that any proposed pharmacological treatments for DMD need to account for the multifactorial nature of this degenerative muscle disease.

\section{Acknowledgements}

We would like to thank the National Health \& Medical Research Council and Australian Research Council for providing financial support. NW holds a Rolf Edgar Lake Fellowship from the Faculty of Medicine, University of Sydney. EY receives support from Internal Competitive Research Grants (A-PE65 \& A-PF31) from Hong Kong Polytechnic University.

\section{References}

1. Hoffman EP, Brown RH, Jr., Kunkel LM. Dystrophin: the protein product of the Duchenne muscular dystrophy locus. Cell 1987; 51: 919-28.

2. Collins CA, Morgan JE. Duchenne's muscular dystrophy: animal models used to investigate pathogenesis and develop therapeutic strategies. Int. J. Exp. Pathol. 2003; 84: 165-72.

3. Oberc MA, Engel WK. Ultrastructural localization of calcium in normal and abnormal skeletal muscle. 


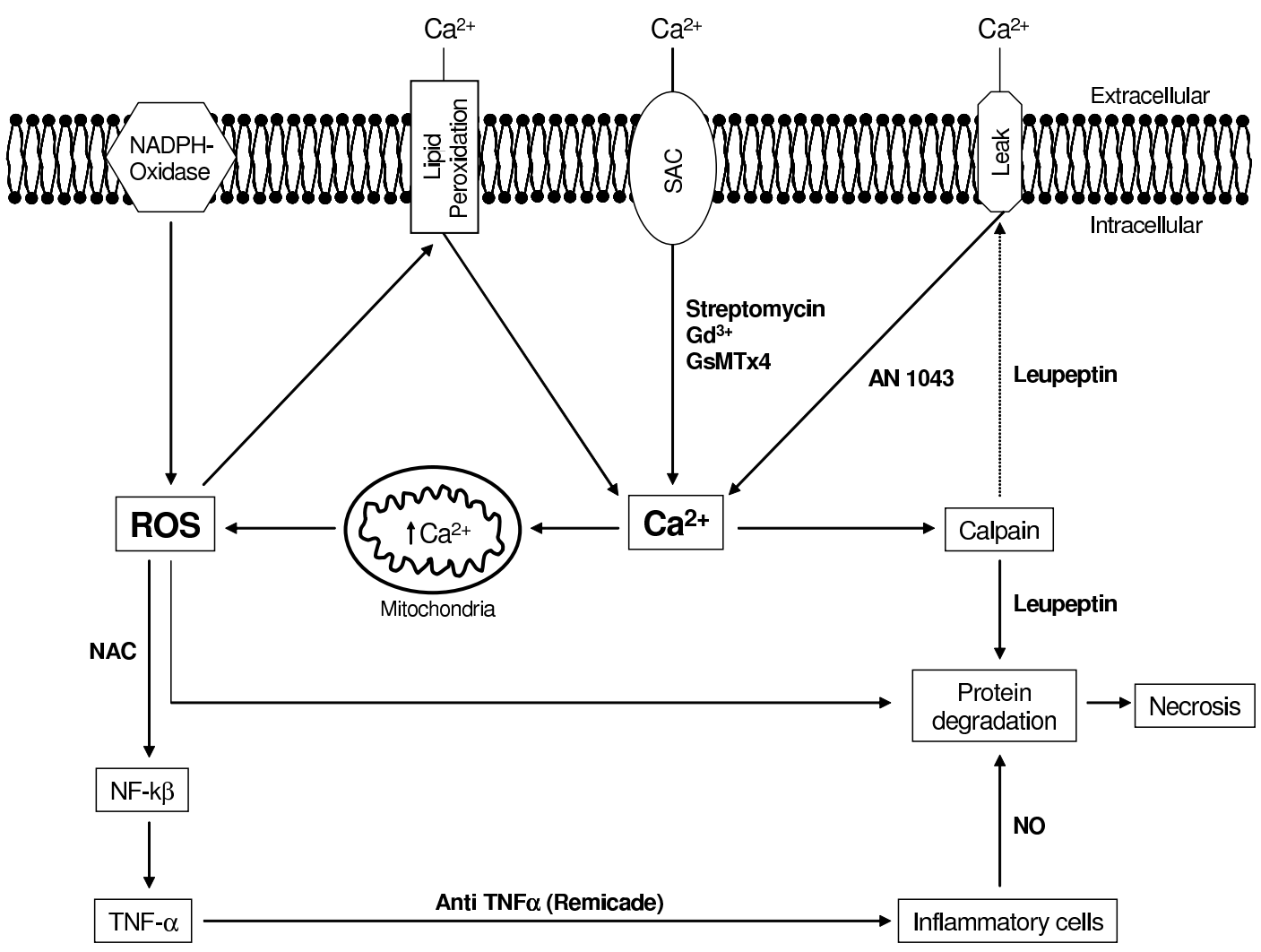

Figure 1. A schematic diagram showing some of the possible damage pathways in a dystrophic muscle fibre, due to increased $\left[\mathrm{Ca}^{2+}\right]_{i}$ and $\mathrm{ROS}$ (see text for details). Chemical agents known to block particular pathways are indicated next to arrows (in bold).

Lab Invest 1977; 36: 566-77.

4. Gailly P. New aspects of calcium signaling in skeletal muscle cells: implications in Duchenne muscular dystrophy. Biochim. Biophys. Acta 2002; 1600: 38-44.

5. Gillis JM. Understanding dystrophinopathies: an inventory of the structural and functional consequences of the absence of dystrophin in muscles of the $m d x$ mouse. J. Muscle Res. Cell Motil. 1999; 20: 605-25.

6. Hopf FW, Reddy P, Hong J, Steinhardt RA. A capacitative calcium current in cultured skeletal muscle cells is mediated by the calcium-specific leak channel and inhibited by dihydropyridine compounds. J. Biol. Chem. 1996; 271: 22358-67.

7. Robert V, Massimino ML, Tosello V, Marsault R, Cantini M, Sorrentino V, Pozzan T. Alteration in calcium handling at the subcellular level in $m d x$ myotubes. J Biol. Chem. 2001; 276: 4647-51.

8. Mallouk N, Jacquemond V, Allard B. Elevated subsarcolemmal $\mathrm{Ca}^{2+}$ in $m d x$ mouse skeletal muscle fibers detected with $\mathrm{Ca}^{2+}$-activated $\mathrm{K}+$ channels. Proc. Natl. Acad. Sci. U.S.A. 2000; 97: 4950-5.

9. Lansman JB, Franco A. What does dystrophin do in normal muscle? J. Muscle Res. Cell Motil. 1991; 12:
409-11.

10. Petrof BJ, Shrager JB, Stedman HH, Kelly AM, Sweeney HL. Dystrophin protects the sarcolemma from stresses developed during muscle contraction. Proc. Natl. Acad. Sci. U.S.A. 1993; 90: 3710-4.

11. Franco A, Jr., Lansman JB. Calcium entry through stretch-inactivated ion channels in $m d x$ myotubes. Nature 1990; 344: 670-3.

12. Ohlendieck K, Campbell KP. Dystrophin-associated proteins are greatly reduced in skeletal muscle from $m d x$ mice. J. Cell Biol. 1991; 115: 1685-94.

13. Head SI, Williams DA, Stephenson DG. Abnormalities in structure and function of limb skeletal muscle fibres of dystrophic $m d x$ mice. Proc. R. Soc. Lond B. 1992; 248: 163-9.

14. Clarke MS, Khakee R, McNeil PL. Loss of cytoplasmic basic fibroblast growth factor from physiologically wounded myofibers of normal and dystrophic muscle. J. Cell Sci. 1993; 106: 121-33.

15. Moens P, Baatsen PH, Marechal G. Increased susceptibility of EDL muscles from $m d x$ mice to damage induced by contractions with stretch. $J$. Muscle Res. Cell Motil. 1993; 14: 446-51.

16. McArdle A, Edwards RH, Jackson MJ. Time course of changes in plasma membrane permeability in the 
dystrophin-deficient $m d x$ mouse. Muscle Nerve 1994; 17: 1378-84.

17. Bogdanovich S, Krag TO, Barton ER, Morris LD, Whittemore LA, Ahima RS, Khurana TS. Functional improvement of dystrophic muscle by myostatin blockade. Nature 2002; 420: 418-21.

18. Hoyte K, Jayasinha V, Xia B, Martin PT. Transgenic overexpression of dystroglycan does not inhibit muscular dystrophy in $m d x$ mice. Am. J. Pathol. 2004; 164: 711-8.

19. Pasternak C, Wong S, Elson EL. Mechanical function of dystrophin in muscle cells. J. Cell Biol. 1995; 128: $355-61$.

20. Hutter OF, Burton FL, Bovell DL. Mechanical properties of normal and $m d x$ mouse sarcolemma: bearing on function of dystrophin. J Muscle Res. Cell Motil. 1991; 12: 585-9.

21. Hutter OF. The membrane hypothesis of Duchenne muscular dystrophy: quest for functional evidence. $J$ Inherit. Metab Dis. 1992; 15: 565-77.

22. Turner PR, Fong PY, Denetclaw WF, Steinhardt RA. Increased calcium influx in dystrophic muscle. $J$. Cell Biol. 1991; 115: 1701-12.

23. Alderton JM, Steinhardt RA. Calcium influx through calcium leak channels is responsible for the elevated levels of calcium-dependent proteolysis in dystrophic myotubes. J Biol. Chem. 2000; 275: 9452-60.

24. Turner PR, Schultz R, Ganguly B, Steinhardt RA. Proteolysis results in altered leak channel kinetics and elevated free calcium in $m d x$ muscle. J. Membr. Biol. 1993; 133: 243-51.

25. Alderton JM, Steinhardt RA. How calcium influx through calcium leak channels is responsible for the elevated levels of calcium-dependent proteolysis in dystrophic myotubes. Trends Cardiovasc. Med. 2000; 10: 268-72.

26. Franco-Obregon A, Jr., Lansman JB. Mechanosensitive ion channels in skeletal muscle from normal and dystrophic mice. J. Physiol. 1994; 481: 299-309.

27. Squire S, Raymackers JM, Vandebrouck C, Potter A, Tinsley J, Fisher R, Gillis JM, Davies KE. Prevention of pathology in $m d x$ mice by expression of utrophin: analysis using an inducible transgenic expression system. Hum. Mol. Genet. 2002; 11: 3333-44.

28. Vandebrouck C, Martin D, Colson-Van Schoor M, Debaix H, Gailly P. Involvement of TRPC in the abnormal calcium influx observed in dystrophic $(m d x)$ mouse skeletal muscle fibers. J Cell Biol. 2002; 158: 1089-96.

29. Yeung EW, Head SI, Allen DG. Gadolinium reduces short-term stretch-induced muscle damage in isolated $m d x$ mouse muscle fibres. J. Physiol. 2003; 552: 449-58.

30. Yeung EW, Whitehead NP, Suchyna TM, Gottlieb PA, Sachs F, Allen DG. Effects of stretch-activated channel blockers on $\left[\mathrm{Ca}^{2+}\right]_{i}$ and muscle damage in the $m d x$ mouse. J. Physiol. 2005; 562: 367-80.
31. Suchyna TM, Johnson JH, Hamer K, Leykam JF, Gage DA, Clemo HF, Baumgarten CM, Sachs F. Identification of a peptide toxin from Grammostola spatulata spider venom that blocks cation-selective stretch-activated channels. J. Gen. Physiol. 2000; 115: 583-98.

32. Wagner KR, Hamed S, Hadley DW, Gropman AL, Burstein AH, Escolar DM, Hoffman EP, Fischbeck KH. Gentamicin treatment of Duchenne and Becker muscular dystrophy due to nonsense mutations. Ann. Neurol. 2001; 49: 706-11.

33. Maroto R, Raso A, Wood TG, Kurosky A, Martinac B, Hamill OP. TRPC1 forms the stretch-activated cation channel in vertebrate cells. Nat. Cell Biol. 2005; 7: 179-85.

34. Shibuya S, Wakayama Y, Inoue M, Oniki H, Kominami E. Changes in the distribution and density of caveolin 3 molecules at the plasma membrane of $m d x$ mouse skeletal muscles: a fracture-label electron microscopic study. Neurosci. Lett. 2002; 325: 171-4.

35. Tang Z, Scherer PE, Okamoto T, Song K, Chu C, Kohtz DS, Nishimoto I, Lodish HF, Lisanti MP. Molecular cloning of caveolin-3, a novel member of the caveolin gene family expressed predominantly in muscle. J. Biol. Chem. 1996; 271: 2255-61.

36. Lockwich TP, Liu X, Singh BB, Jadlowiec J, Weiland S, Ambudkar IS. Assembly of Trp1 in a signaling complex associated with caveolin-scaffolding lipid raft domains. J Biol. Chem. 2000; 275: 11934-42.

37. Paria BC, Vogel SM, Ahmmed GU, Alamgir S, Shroff J, Malik $\mathrm{AB}$ and Tiruppathi C. Tumor necrosis factor-alpha-induced TRPC1 expression amplifies store-operated $\mathrm{Ca}^{2+}$ influx and endothelial permeability. Am. J. Physiol. 2004; 287: L1303-L1313.

38. Kumar A, Boriek AM. Mechanical stress activates the nuclear factor-kappaB pathway in skeletal muscle fibers: a possible role in Duchenne muscular dystrophy. FASEB J. 2003; 17: 386-96.

39. Sotgia F, Lee JK, Das K, Bedford M, Petrucci TC, Macioce P, Sargiacomo M, Bricarelli FD, Minetti C, Sudol M, Lisanti MP. Caveolin-3 directly interacts with the C-terminal tail of beta -dystroglycan. Identification of a central WW-like domain within caveolin family members. J Biol. Chem. 2000; 275: 38048-58.

40. Turner PR, Westwood T, Regen CM, Steinhardt RA. Increased protein degradation results from elevated free calcium levels found in muscle from $m d x$ mice. Nature 1988; 335: 735-8.

41. Zaidi SI, Narahara HT. Degradation of skeletal muscle plasma membrane proteins by calpain. J. Membr. Biol. 1989; 110: 209-16.

42. Goll DE, Thompson VF, Li H, Wei W, Cong J. The calpain system. Physiol. Rev. 2003; 83: 731-801.

43. Bonuccelli G, Sotgia F, Schubert W, Park DS, Frank PG, Woodman SE, Insabato L, Cammer M, Minetti C, Lisanti MP. Proteasome inhibitor (MG-132) 
treatment of mdx mice rescues the expression and membrane localization of dystrophin and dystrophin-associated proteins. Am. J. Pathol. 2003; 163: 1663-75.

44. Spencer MJ, Croall DE, Tidball JG. Calpains are activated in necrotic fibers from $m d x$ dystrophic mice. J. Biol. Chem. 1995; 270: 10909-14.

45. Badalamente MA, Stracher A. Delay of muscle degeneration and necrosis in $m d x$ mice by calpain inhibition. Muscle Nerve 2000; 23: 106-11.

46. Spencer MJ, Mellgren RL. Overexpression of a calpastatin transgene in $m d x$ muscle reduces dystrophic pathology. Hum. Mol. Genet. 2002; 11: 2645-55.

47. Rando TA, Disatnik MH, Yu Y, Franco A. Muscle cells from $m d x$ mice have an increased susceptibility to oxidative stress. Neuromuscul. Disord. 1998; 8: 14-21.

48. Disatnik MH, Dhawan J, Yu Y, Beal MF, Whirl MM, Franco AA, Rando TA. Evidence of oxidative stress in $m d x$ mouse muscle: studies of the pre-necrotic state. J. Neurol. Sci. 1998; 161: 77-84.

49. Buetler TM, Renard M, Offord EA, Schneider H, Ruegg UT. Green tea extract decreases muscle necrosis in $m d x$ mice and protects against reactive oxygen species. Am. J. Clin. Nutr. 2002; 75: 749-53.

50. Bornman L, Rossouw H, Gericke GS, Polla BS. Effects of iron deprivation on the pathology and stress protein expression in murine X-linked muscular dystrophy. Biochem. Pharmacol. 1998; 56: 751-7.

51. Backman E, Nylander E, Johansson I, Henriksson KG, Tagesson C. Selenium and vitamin E treatment of Duchenne muscular dystrophy: no effect on muscle function. Acta Neurol. Scand. 1988; 78: 429-35.

52. Fenichel GM, Brooke MH, Griggs RC, Mendell JR et al. Clinical investigation in Duchenne muscular dystrophy: penicillamine and vitamin E. Muscle Nerve 1988; 11: 1164-8.

53. Brookes PS, Yoon Y, Robotham JL, Anders MW, Sheu SS. Calcium, ATP, and ROS: a mitochondrial lovehate triangle. Am. J Physiol. 2004; 287: C817-C833.

54. Nethery D, Callahan LA, Stofan D, Mattera R, DiMarco A, Supinski G. PLA(2) dependence of diaphragm mitochondrial formation of reactive oxygen species. J. Appl. Physiol. 2000; 89: 72-80.

55. Kuznetsov AV, Winkler K, Wiedemann FR, von Bossanyi P, Dietzmann K, Kunz WS. Impaired mitochondrial oxidative phosphorylation in skeletal muscle of the dystrophin-deficient $m d x$ mouse. Mol. Cell Biochem. 1998; 183: 87-96.

56. Howl JD, Publicover SJ. Permeabilisation of the sarcolemma in mouse diaphragm exposed to Bay $\mathrm{K}$ 8644 in vitro: time course, dependence on $\mathrm{Ca}^{2+}$ and effects of enzyme inhibitors. Acta Neuropathol. 1990; 79: 438-43.

57. Lindahl M, Backman E, Henriksson KG, Gorospe JR, Hoffman EP. Phospholipase A2 activity in dystrophinopathies. Neuromuscul. Disord. 1995; 5: 193-9.
58. Sevanian A, Kim E. Phospholipase A2 dependent release of fatty acids from peroxidized membranes. J. Free Radic. Biol. Med. 1985; 1: 263-71.

59. Amma $H$, Naruse $K$, Ishiguro $N$, Sokabe $M$. Involvement of reactive oxygen species in cyclic stretch-induced NF-kappaB activation in human fibroblast cells. Br. J. Pharmacol. 2005.

60. Grote K, Flach I, Luchtefeld M, Akin E, Holland SM, Drexler H, Schieffer B. Mechanical stretch enhances mRNA expression and proenzyme release of matrix metalloproteinase-2 (MMP-2) via NAD(P)H oxidase-derived reactive oxygen species. Circ. Res. 2003; 92: e80-e86.

61. Javesghani D, Magder SA, Barreiro E, Quinn MT, Hussain SN. Molecular characterization of a superoxide-generating $\mathrm{NAD}(\mathrm{P}) \mathrm{H}$ oxidase in the ventilatory muscles. Am. J. Respir. Crit Care Med. 2002; 165: 412-8.

62. Reid MB, Li YP. Cytokines and oxidative signalling in skeletal muscle. Acta Physiol. Scand. 2001; 171: 225-32.

63. Grounds MD, Torrisi J. Anti-TNFalpha (Remicade) therapy protects dystrophic skeletal muscle from necrosis. FASEB J. 2004; 18: 676-82.

64. Tidball JG. Inflammatory processes in muscle injury and repair. Am. J. Physiol. 2005; 288: R345-R353.

65. Wehling M, Spencer MJ, Tidball JG. A nitric oxide synthase transgene ameliorates muscular dystrophy in $m d x$ mice. J. Cell Biol. 2001; 155: 123-31.

Received 20 June 2005, in revised form 14 September 2005. Accepted 21 September 2005.

CD.G. Allen 2005.

Author for correspondence:

Nicholas P. Whitehead,

School of Medical Sciences,

University of Sydney (F13),

NSW 2006,

Australia

Tel: +61293514526

Fax: +61293512058

E-mail: nickw@physiol.usyd.edu.au 